\title{
Toll-like receptors 7 and 8 expression correlates with the expression of immune biomarkers and positively predicts the clinical outcome of patients with melanoma [Corrigendum]
} Zhang MC, Yan ZL, Wang JJ, Yao XQ. Onco Targets Ther.
2017;10:4339-4346.

On page 4339, the correspondence was listed as:

\section{Correspondence: Xueqing Yao}

Department of General Surgery, Guangdong General Hospital and Guangdong Academy of Medical Sciences, 106 Zhongshan 2nd Road,

Guangzhou, Guangdong 510080, China

Tel +86 I3902388635

Email yjb92I I@2Icn.com
It should have been:

Correspondence: Xueqing Yao',2

'Second Clinical Medical College of Southern Medical University, 1838 Guangzhou Avenue North, Guangzhou, Guangdong 5105I5, China; ${ }^{2}$ Department of General Surgery, Guangdong General Hospital and Guangdong Academy of Medical Sciences, 106 Zhongshan 2nd Road, Guangzhou, Guangdong 510080, China

Tel +8613902388635

Email yjb92II@2Icn.com
OncoTargets and Therapy

\section{Publish your work in this journal}

OncoTargets and Therapy is an international, peer-reviewed, open access journal focusing on the pathological basis of all cancers, potential targets for therapy and treatment protocols employed to improve the management of cancer patients. The journal also focuses on the impact of management programs and new therapeutic agents and protocols on

\section{Dovepress}

patient perspectives such as quality of life, adherence and satisfaction. The manuscript management system is completely online and includes a very quick and fair peer-review system, which is all easy to use. Visit http://www.dovepress.com/testimonials.php to read real quotes from published authors. 